\title{
Influence of $\mathrm{GdVO}_{4}: \mathrm{Eu}^{3+}$ Nanocrystals on Growth, Germination, Root Cell Viability and Oxidative Stress of Wheat (Triticum aestivum L.) Seedlings
}

\author{
Anna Ekner-Grzyb ${ }^{1, *} \mathbb{D}$, Jagna Chmielowska-Bąk ${ }^{1}(\mathbb{D})$ and Agata Szczeszak ${ }^{2}$ \\ 1 Department of Plant Ecophysiology, Faculty of Biology, Institute of Experimental Biology, \\ Adam Mickiewicz University, Uniwersytetu Poznańskiego 6, 61-614 Poznań, Poland; \\ jagna.chmielowska@amu.edu.pl \\ 2 Department of Rare Earths, Faculty of Chemistry, Adam Mickiewicz University, \\ Uniwersytetu Poznańskiego 8, 61-614 Poznań, Poland; agata_is@amu.edu.pl \\ * Correspondence: aekner@amu.edu.pl; Tel.: +48-61-829-5811
}

\section{check for}

updates

Citation: Ekner-Grzyb, A.;

Chmielowska-Bąk, J.; Szczeszak, A.

Influence of $\mathrm{GdVO}_{4}: \mathrm{Eu}^{3+}$

Nanocrystals on Growth,

Germination, Root Cell Viability and

Oxidative Stress of Wheat (Triticum

aestivum L.) Seedlings. Plants 2021, 10,

1187. https://doi.org/10.3390/

plants10061187

Academic Editor:

Barbara Hawrylak-Nowak

Received: 18 May 2021

Accepted: 7 June 2021

Published: 10 June 2021

Publisher's Note: MDPI stays neutral with regard to jurisdictional claims in published maps and institutional affiliations.

Copyright: (C) 2021 by the authors. Licensee MDPI, Basel, Switzerland. This article is an open access article distributed under the terms and conditions of the Creative Commons Attribution (CC BY) license (https:// creativecommons.org/licenses/by/ $4.0 /)$.
Abstract: The increasing application of lanthanide-doped nanocrystals (LDNCs) entails the risk of a harmful impact on the natural environment. Therefore, in the presented study the influence of gadolinium orthovanadates doped with $\mathrm{Eu}^{3+}\left(\mathrm{GdVO}_{4}: \mathrm{Eu}^{3}\right)$ nanocrystals on wheat (Triticum aestivum L.), chosen as a model plant species, was investigated. The seeds were grown in Petri dishes filled with colloids of LDNCs at the concentrations of $0,10,50$ and $100 \mu \mathrm{g} / \mathrm{mL}$. The plants' growth endpoints (number of roots, roots length, roots mass, hypocotyl length and hypocotyl mass) and germination rate were not significantly changed after the exposure to $\mathrm{GdVO}_{4}: \mathrm{Eu}^{3+}$ nanocrystals at all used concentrations. The presence of LDNCs also had no effect on oxidative stress intensity, which was determined on the basis of the amount of lipid peroxidation product (thiobarbituric acid reactive substances; TBARS) in the roots. Similarly, TTC (tetrazolium chloride) assay did not show any differences in cells' viability. However, root cells of the treated seedlings contained less Evans Blue (EB) when compared to the control. The obtained results, on the one hand, suggest that $\mathrm{GdVO}_{4}: \mathrm{Eu}^{3+}$ nanocrystals are safe for plants in the tested concentrations, while on the other hand they indicate that LDNCs may interfere with the functioning of the root cell membrane.

Keywords: nanotoxicology; lanthanide-doped nanoparticles; vascular plants; phytotoxicity; lipid peroxidation; cell viability

\section{Introduction}

Recently, a growing interest in the use of nanoparticles (NPs) has been observed. Their unique properties have been utilized in chemical and biological sciences, medicine, as well as in industry and agriculture. However, along with many advantages, their use entails some risks. They can enter the environment and may have impact on the wildlife and human health [1-3]. The effects of NPs may be completely different to those of their larger counterparts (bulk materials) [4-7]. These differences result from the higher surface area to volume ratio and higher surface reactivity of nanostructures compared to the bulk compounds. Moreover, due to their smaller size NPs can enter organisms more easily as compared to bulk structures [4], although this is not always the case [5].

Previous research has shown that NPs are taken up by plants and they are subsequently spread and accumulated in the tissues, mainly in roots, stems and leaves [8-11]. The NPs influence the contaminated plants in many ways [12-14]. They may negatively affect germination, cells morphology, growth rate or final biomass of plants and induce oxidative stress [6,15-23]. However, some authors have found no negative consequences or have even observed a biostimulating effect of NPs on plants including Avena sativa L., Zea mays L., Lycopersicon esculentum L., Lepidium sativum, Sinapis alba, Sorghum saccharatum, 
Lactuca sativa L. and Triticum aestivum L. [24-28]. The positive effect occurred mainly at low concentrations and was reversed at higher doses of NPs $[16,17]$. For example, Peng and co-authors showed that $\mathrm{NaYF}_{4}: \mathrm{Yb}^{3+}, \mathrm{Er}^{3+}, \mathrm{Tm}^{3+}$ coated with citric acid reduced the growth rate of mung beans at concentrations of $100 \mu \mathrm{g} / \mathrm{mL}$, whereas a concentration of $10 \mu \mathrm{g} / \mathrm{mL}$ improved the development of the plants [16]. The improvement in growth may be caused by more effective uptake of water or nutrients in plants exposed to NPs $[17,26,29]$, as well as interference with the toxic metals taken up from the medium [30,31]. The overall effect of NPs on plants depends on numerous factors, such as time of the exposure, surface contamination, size, plants species, etc. [32-35].

Inorganic nanocrystals doped with lanthanide ions (lanthanide-doped nanocrystals, LDNCs) have been widely investigated. Their unique spectroscopic properties, such as their luminescence properties, resistance to photobleaching and photochemical degradation have been found very attractive for many potential applications [36,37]. LDNCs are used in innovative technologies, the optoelectronic industry (e.g., LCD), agriculture, as well as biological and medical sciences (e.g., drug delivery and bioimaging) [38-41]. Among them, gadolinium-based LDNCs such as vanadates gadolinium doped with $\mathrm{Eu}^{3+}$ ions $\left(\mathrm{GdVO}_{4}: \mathrm{Eu}^{3}\right)$ may be applied as catalysis, polarizers, laser hosts and luminescent materials $[42,43]$. Moreover, $\mathrm{GdVO}_{4}: \mathrm{Eu}^{3+} \mathrm{NPs}$ can be used in biological and medical science, e.g., for magnetic resonance imaging (MRI) and drug delivery [44-49].

Nanostructures used in the above-mentioned applications may be transferred to the environment. According to a study in California, the highest amount of gadolinium was observed in the water bodies close to hospitals and medical centers. This discovery suggests that the Gd-based contrast agents used for magnetic resonance imaging are the main source of contamination [50]. Gadolinium may also accumulate in animal tissues, such as the human brain [51]. A study of vertebrate cell lines has revealed that gadolinium may influence the vertebrate cells, e.g., cause apoptosis [52]. Wysokińska et al. have reported that $\mathrm{NaGdF}_{4}: \mathrm{Yb}^{3+}, \mathrm{Er}^{3+}, \mathrm{NaGdF}_{4}$ or $\mathrm{NaGdF}_{4}: \mathrm{Eu}^{3+} \mathrm{NPs}$ may negatively affect the viability of macrophages and fibroblasts [39]. Our previous study conducted on LDNCs similar to those used in this study shown that $\mathrm{Fe}_{3} \mathrm{O}_{4} @ \mathrm{SiO}_{2} @ \mathrm{GdVO}_{4}: \mathrm{Eu}^{3+} 5 \%$ core@shell type nanostructure had no effect on the erythrocyte sedimentation rate, morphology of red blood cells or their membrane permeability when present in concentrations up to $1 \mathrm{mg} / \mathrm{mL}$ [53]. However, our other research has shown that the effect of $\mathrm{GdVO}_{4}: \mathrm{Eu}^{3+} 5 \%$ depends on the surface functionalization, kind of cells and concentration [54].

Few authors have shown interest in the toxicity of LDNCs to plants. According to the literature data, LDNCs may be taken up by particular parts of plants and their presence may influence plant development, similarly to other nanostructures $[9,10,16-18,55,56]$. Moreover, most of the previously published data on the phytotoxicity of LDNCs concerns fluorides, mainly $\mathrm{NaYF}_{4}[9,10,16,17,57]$ or oxides [18]. According to the current state of knowledge, no data have been published on the phytotoxicity of vanadates gadolinium doped with europium ions. In the present study, the impact of $\mathrm{GdVO}_{4}: \mathrm{Eu}^{3+} \mathrm{NPs}$ on wheat seedlings was investigated.

\section{Results}

\subsection{Nanoparticles Characterisation and Elemental Analysis}

The NPs' structure and morphology were characterized on the basis of DLS measurements and TEM images. DLS analysis showed that the hydrodynamic diameter of NPs, including their agglomerates, varies between 140 and $180 \mathrm{~nm}$ (Figure 1a). Furthermore, TEM image analysis confirmed that NPs form agglomerates with an average grain size of $70 \pm 5 \mathrm{~nm}$. Additionally, a negative zeta potential $(-20.0 \pm 4.29 \mathrm{mV})$ indicates that NPs colloids are stable at physiological $\mathrm{pH}$ and appropriate to use as water colloids [44]. To show the stability and transparency of $\mathrm{GdVO}_{4}: \mathrm{Eu}^{3+} \mathrm{NPs}$ aqueous colloids at a concentration of $10 \mathrm{mg} / \mathrm{mL}$, pictures were taken in daylight (Figure 1b, left side). Furthermore, red luminescence under $254 \mathrm{~nm}$ UV excitation related to the presence of $\mathrm{Eu}^{3+}$ emitting ions was also performed (Figure 1b, right side). 


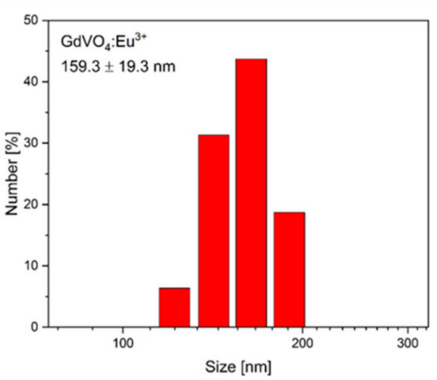

(a)

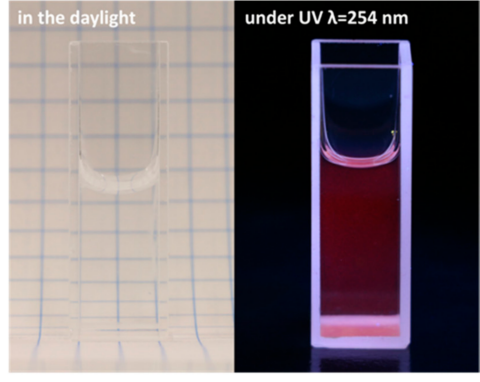

(b)

Figure 1. DLS analysis of the $\mathrm{GdVO}_{4}: \mathrm{Eu}^{3+} \mathrm{NPs}(\mathbf{a})$. Photographs presenting the colloidal $\mathrm{GdVO}_{4}: \mathrm{Eu}^{3+}$ NPs in daylight (left) and under $254 \mathrm{~nm}$ UV light excitation (right) (b).

ICP-OES analysis revealed that the LDNCs were taken up by the wheat seedlings.

\subsection{Growth and Germination of the Seedlings}

Treatment with $\mathrm{GdVO}_{4}: \mathrm{Eu}^{3+} \mathrm{NPs}$ had no significant impact on the morphology of wheat seedlings. The influence of the $\mathrm{GdVO}_{4}: \mathrm{Eu}^{3+} \mathrm{NPs}$ on several growth endpoints, including the number of roots, root length, hypocotyl length, root mass and hypocotyl mass was investigated. These parameters were not significantly changed as a result of the plants' exposure to 10,50 and $100 \mu \mathrm{g} / \mathrm{mL}$ of LDNCs for 3 days, relative to the controls (Kruskal-Wallis test, $p>0.1$; Figure 2a-e). The studied LDNCs also did not affect the germination rate of the tested concentrations (Kruskal-Wallis test, $p>0.1$; Figure 2f).
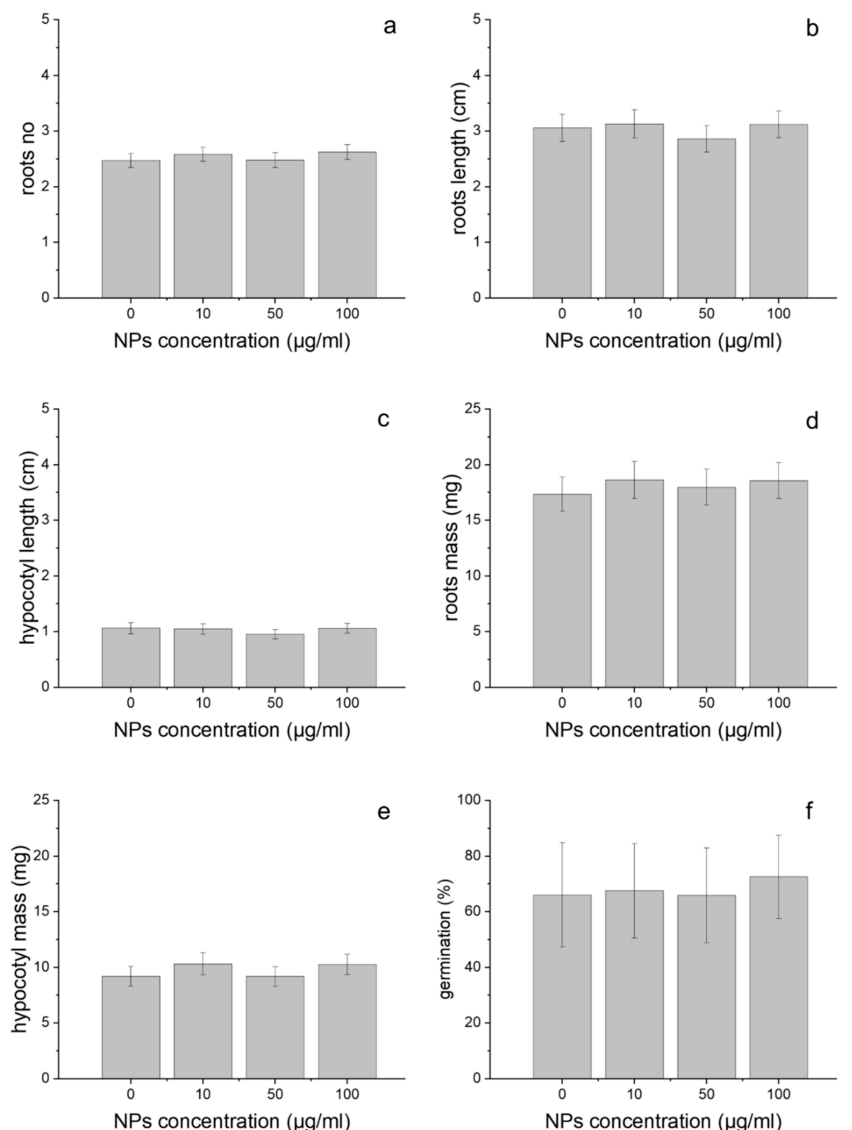

Figure 2. Number of roots (a), root length (b), hypocotyl length (c), root mass (d), hypocotyl mass (e) and germination rate (f) of wheat, treated for 3 days with the $\mathrm{GdVO}_{4}: \mathrm{Eu}^{3+} \mathrm{NPs}$ at concentrations: 0 , 10,50 and $100 \mu \mathrm{g} / \mathrm{mL}$. The results are presented as mean $\pm \mathrm{SE}$. 


\subsection{Oxidative Stress}

The degree of lipid peroxidation, estimated on the basis of the amount of TBARS did not change during the experiments. Treatments of the wheat with $\mathrm{GdVO}_{4}: \mathrm{Eu}^{3+} \mathrm{NPs}$ did not affect this factor, at all tested concentrations (ANOVA, $p=0.36$; Figure 3 ).

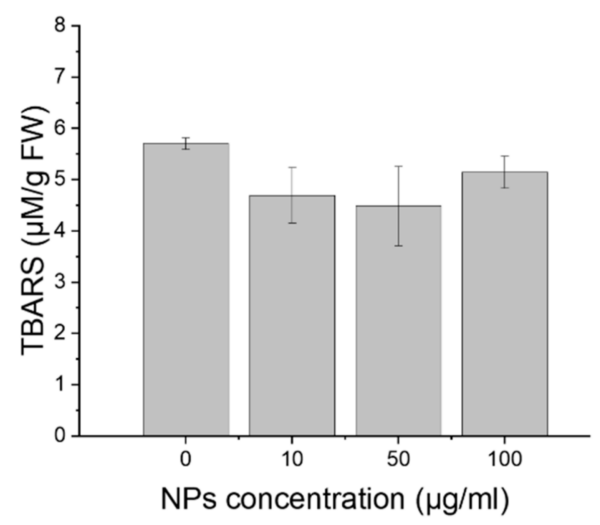

Figure 3. Lipid peroxidation of wheat cells, treated for 3 days with the $\mathrm{GdVO}_{4}: \mathrm{Eu}^{3+} \mathrm{NPs}$ at concentrations: $0,10,50$ and $100 \mu \mathrm{g} / \mathrm{mL}$. The results are presented as mean $\pm \mathrm{SE}$.

\subsection{Cell Viability}

The results of TTC staining showed that the exposure of the cells to $\mathrm{GdVO}_{4}: \mathrm{Eu}^{3+}$ NPs had no impact on the amount of formazan level (ANOVA, $p=0.83$; Figure $4 a$ ). However, BE uptake was significantly different in control root cells and the cells incubated with LDNCs (ANOVA, $p<0.005$ ). The roots growing in the medium without LDNCs contained significantly more BE dye than those growing in the medium with NPs, both at the $10 \mu \mathrm{g} / \mathrm{mL}$ (Tukey's test, $p<0.05$ ) and the 50 or $100 \mu \mathrm{g} / \mathrm{mL}$ (Tukey's test, $p<0.01$ ) concentrations (Figure 4b).
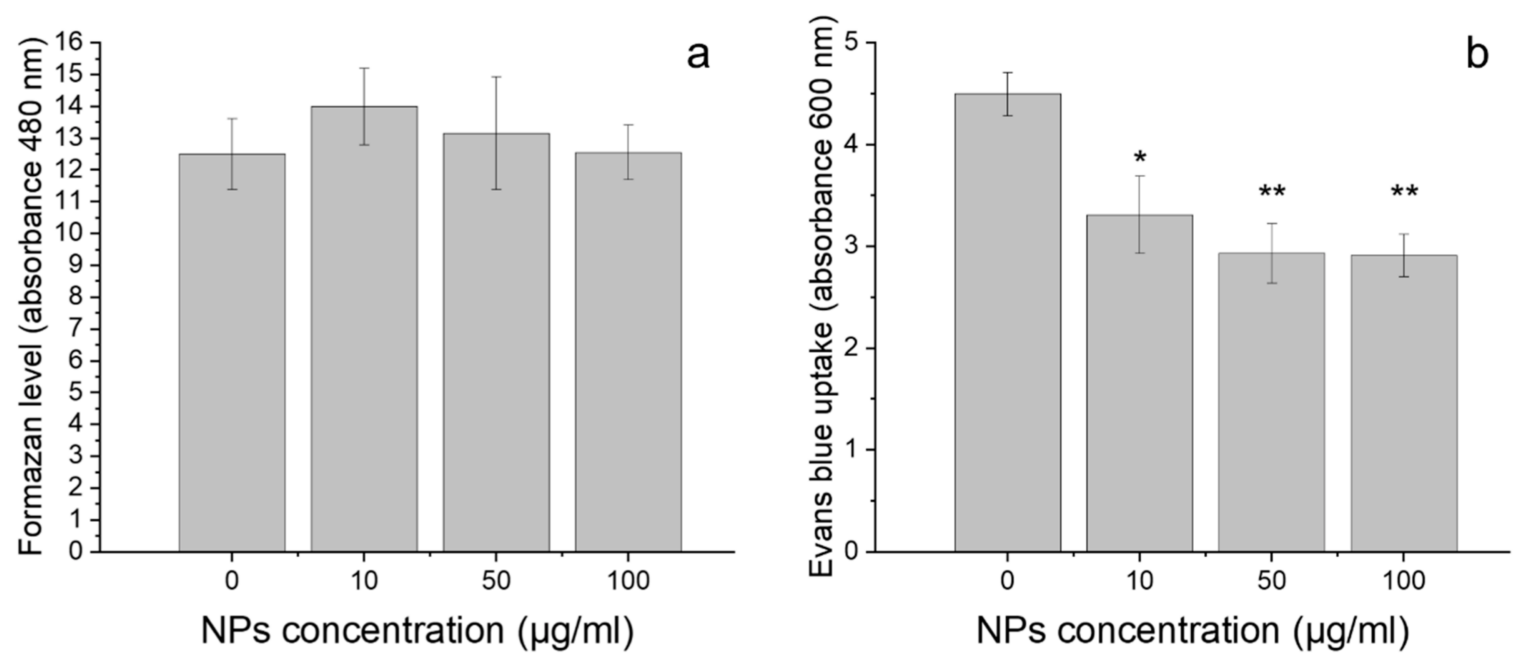

Figure 4. Cell viability of wheat exposed for 3 days to $\mathrm{GdVO}_{4}: \mathrm{Eu}^{3+} \mathrm{NPs}$ at concentrations: $0,10,50 \mathrm{and} 100 \mu \mathrm{g} / \mathrm{mL}$, determined by TTC (a) and Blue Evans (b) staining assays. Asterisks $\left(^{*}\right)$ indicate statistically significant differences between the samples exposed to NPs and the control, Tukey's test $\left({ }^{*} p<0.05\right.$ level, ${ }^{* *} p<0.01$ level). The results are presented as mean $\pm S E$.

\section{Discussion}

In the presented study, wheat seeds were incubated with $\mathrm{GdVO}_{4}: \mathrm{Eu}^{3+} \mathrm{NPs}$ for 3 days. Even after this short treatment time, the presence of LDNCs was detected inside the plants. However, results of the plants' growth assays showed that $\mathrm{GdVO}_{4}: \mathrm{Eu}^{3+} \mathrm{NPs}$ had no significant effect on germination rate, seedling elongation and biomass of plants, when used 
in all tested concentrations (Figure 2). According to the current state of knowledge, there are no previous studies on the phytotoxicity of $\mathrm{GdVO}_{4}: \mathrm{Eu}^{3+} \mathrm{NPs}$. Although the LDNPs studied are poorly water soluble [58], some small amounts of the ions can be released to the solutions. Therefore, along with checking the influence of $\mathrm{GdVO}_{4}: \mathrm{Eu}^{3+} \mathrm{NPs}$ on wheat plants, we have to consider the effect of their particular compounds (e.g., ions). Similarly to our findings for wheat, Blinova et al. suggested that the oxides containing gadolinium $\left(\mathrm{Ce}_{0.9} \mathrm{Gd}_{0.1} \mathrm{O}_{2}, \mathrm{LaFeO}_{3}, \mathrm{Gd}_{0.97} \mathrm{CoO}_{3}\right)$ were not toxic for Lemna minor even at $100 \mu \mathrm{g} / \mathrm{mL}$ [59]. According to other authors, gadolinium caused growth inhibition of Chlorophyta [18,29], although Romero-Freire suggest that this effect was observed only when $\mathrm{Gd}^{3+}$ ions were mixed with $\mathrm{Ce}^{3+}$ and $\mathrm{Lu}^{3+}$ lanthanide ions. In another study, $\mathrm{Gd}_{2} \mathrm{O}_{3}$ NPs caused a decrease in roots' growth of Triticum aestivum and Brassica napus [60]. This effect depended on the sequence of processes of soaking and incubating during treatments. In the same study, germination of wheat and rape seeds was not affected by the presence of gadolinium oxides NPs [60]. However, Gd ${ }^{3+}$ ions significantly decreased shoot growth of Zea mays at $10 \mu \mathrm{g} / \mathrm{mL}$ [61]. Ruíz-Herrera et al. have shown that $\mathrm{GdCl}_{3}$ affects the length of primary roots in a dose-dependent manner [62]. Unexpectedly, the same study revealed that with an increasing concentration of gadolinium ions, the total number of lateral roots per plant and lateral roots' density increased [62]. It has been reported that europium, another lanthanide component of the studied $\mathrm{GdVO}_{4}: \mathrm{Eu}^{3+} \mathrm{NPs}$, may accumulate in macrophytes and alter the plants' growth $[63,64]$. The results obtained for one more component of the NPs studied, i.e., vanadium or vanadium oxide, which do not represent lanthanides, have been inconclusive. It has been suggested that plants incubated with a high concentration of vanadium have shorter root length and poorer survival, whereas a low concentration of vanadium may improve the growth rate, accelerate flowering and biomass production [65], see the review in [66].

It has been demonstrated that modulated nutrient content in the tested plants may have an impact on the growth rate. Garcia-Jimenez et al. reported that a solution of $\mathrm{NH}_{4} \mathrm{VO}_{3}$ added at a concentration of $5 \mathrm{mM}$ stimulated the uptake of nutrients by the plants; when the concentration of this compound was increased to $15 \mathrm{mM}$, the stimulating effect was noticeable but reduced. Exposure to $\mathrm{NH}_{4} \mathrm{VO}_{3}$ at $5 \mu \mathrm{M}$ has been found to cause an increase in the level of amino acids and sugars in leaves and roots [65]. Other studies have revealed that the presence of europium causes a decrease in the concentration of macroelements in Lathyrus sativus roots [63]. In the same paper, it was reported that europium activated proteolytic enzymes, and therefore increased the concentration of amino acids in the cells, causing plants to be less vulnerable to an arid environment [63]. Saatz et al. have demonstrated significant correlations between the concentration of gadolinium in the nutrient solution and the concentration of $\mathrm{Ca}, \mathrm{Mg}$ and $\mathrm{P}$ in the root tissues [61]. However, in the present study, it is unlikely that exposure to $\mathrm{GdVO}_{4}: \mathrm{Eu}^{3+} \mathrm{NPs}$ had an impact on seedlings mineral composition as the seedlings were grown in water (or colloids with LDNCs). The differences between the literature data and our results on the growth and development of wheat may be related to several factors, such as differences in the solubility and structures of NPs, as well as the assays' duration. Moreover, the toxicity may depend on the presence of compounds other that the tested one $[30,67]$.

The effect of NPs on lipid peroxidation [19,67-69], see the review in [13], and cell viability $[8,32,68,70]$ has been studied; however, according to the present state of knowledge, the influence of LNDPs on the cell membrane damage and lipid peroxidation in plants has not been studied as yet. However, it has been shown that vanadium ions present at a concentration $50 \mathrm{mg} \mathrm{V}$ in $1 \mathrm{~kg}$ of soil caused cell death, reduction in the membrane integrity and activation of antioxidant enzymes in chickpea Cicer arietinum L. [71]. In our study, the oxidative stress of the seedlings was evaluated by measuring the amount of lipid peroxidation product (thiobarbituric acid reactive substances, TBARS) as a biomarker. The assay showed that the $\mathrm{GdVO}_{4}: \mathrm{Eu}^{3+} \mathrm{NPs}$ did not cause oxidation of the membrane lipid of the wheat root cells when used in all tested concentrations (Figure 3). 
The effect of the NPs presence on the cells' viability was assessed by two methods: TTC and EB assays. They provided different results. According to the TTC results, the presence of LDNCs had no impact on the formazan level, when used in all tested concentrations. This suggests that LDNCs did not cause cell death during the treatment. However, the results of the EB assay revealed that incubation of the seedlings with $\mathrm{GdVO}_{4}: \mathrm{Eu}^{3+} \mathrm{NPs}$ induced significant alterations in cells' staining by EB dye. It has been proved that the presence of EB dye in cells is correlated with the loss of integrity in the plasma membrane of the cells and their mortality [72]. Unexpectedly, in the present study, the control cells had higher absorbance than the treated ones (Figure $4 b$ ). The mechanism of the observed phenomenon is not known, but several explanations can be proposed. First, the obtained results might be caused by the decreased uptake of EB dye by the cells incubated with the LDNCs compared to the control. The LDNCs may create aggregates, and therefore block pores of the cells, which prevents the access of the dye to the inside of the cells. Indeed, it has been shown that NPs might adhere to cell membranes, and thus, they may alert intracellular transport [73]. Alternatively, the LDNCs may interact with ions or structures that are responsible for pumping EB dye out.

\section{Materials and Methods}

\subsection{Nanoparticles Characterisation and Elemental Analysis}

The NPs used for the ecotoxicity investigation were based on an inorganic matrix of orthovanadates doped with $\mathrm{Eu}^{3+}$ ions, $\mathrm{GdVO}_{4}: \mathrm{Eu}^{3+}$, synthesized under hydrothermal conditions. Detailed description of the synthesis method and photophysical characterization of the NPs used are presented in a previous paper [42]. After the synthesis of NPs, the concentration of the stock solution was $3.54 \mathrm{mg} / \mathrm{mL}$ as determined by inductively coupled plasma-optical emission spectrometry (Varian ICP-OES VISTA-MPX). Before the assays, transmission electron microscopy (TEM) images were recorded using an HRTEM JEOL ARM 200F transmission electron microscope at the accelerating voltage of $200 \mathrm{kV}$. Dynamic light scattering (DLS) and zeta potential measurements were performed using a Malvern Zetasizer Nano ZS instrument. The concentration of the colloid sample was $1 \mathrm{mg} / \mathrm{mL}$. Zeta potential was measured at physiological $\mathrm{pH}$.

In order to evaluate the uptake of LDNCs by the plant organisms, elementary analysis was used. After 3 days of incubation, the seedlings were collected, weighed, rinsed, and mineralized in a pressure reactor with $\mathrm{HNO}_{3}$. Next, the samples were analyzed using inductively coupled plasma optical emission spectroscopy (ICP OES).

\subsection{Plant Growth and Treatment}

Wheat (Triticum aestivum L.) seeds were kindly supplied by the Danko Company (Kościan, Poland). The seeds were surface sterilized for $5 \mathrm{~min}$. with $75 \%$ ethanol and another $10 \mathrm{~min}$. with $1 \%$ sodium hypochlorite according to [74]. Afterwards, the seeds were washed with tap water for $30 \mathrm{~min}$. and immersed in distilled water for $10 \mathrm{~min}$.

Next, the seeds were incubated with the $\mathrm{GdVO}_{4}: \mathrm{Eu}^{3+} \mathrm{NPs}$ according to [32], with some modifications. The seeds were placed in Petri dishes (30 seeds per dish) and filled with colloids of LDNCs at the following concentrations: $0,10,50$ or $100 \mu \mathrm{g} / \mathrm{mL}$ of the aqueous solution. The concentrations were determined on the basis of the results of previous studies conducted on similar nanoparticles, in which the authors demonstrated that a concentration of $100 \mu \mathrm{g} / \mathrm{mL}$ and lower were enough for optical and MRI imaging [44,47,49,75]. The colloids were sonicated before all assays. They were grown in the dark at a stable temperature of $22^{\circ} \mathrm{C}$ for 3 days.

\subsection{Measurement of Growth Parameters}

Germination rate, seedling growth (root and hypocotyl length), number of roots and fresh weight (root and hypocotyl mass) were measured. Six replicates (each consisting of 30 seedlings) were run per treatment. 


\subsection{Cell Viability Estimation}

Cell viability was evaluated by two spectrophotometric methods: staining with Evans Blue (EB) and tetrazolium chloride (TTC). The first method is based on the accumulation of EB in cells with damaged membrane. The measurements were performed according to the procedure given in [72] with some modifications. Approximately $200 \mathrm{mg}$ of roots were cut off on the ice and incubated with $0.25 \%$ Evans blue (Sigma, E-2129, St. Louis, MO, USA) for $20 \mathrm{~min}$ at room temperature. Afterwards, the roots were washed twice for $15 \mathrm{~min}$. with distilled water, homogenized in a mortar with the destaining solution $(50 \mathrm{~mL}$ of ethanol, $49 \mathrm{~mL}$ of distilled water, and $1 \mathrm{~mL}$ of $10 \%$ SDS) and incubated in the heating block for $15 \mathrm{~min}$ at $50^{\circ} \mathrm{C}$. Next, the samples were centrifuged $\left(12,000 \mathrm{rpm}, 20^{\circ} \mathrm{C}, 15 \mathrm{~min}\right)$ and the absorbance of the supernatant was measured at $600 \mathrm{~nm}$. Each experiment was repeated four times and all samples in each experiment were tested in duplicate.

The second method consisted of the measurement of the amount of insoluble red formazan that accumulated in living cells as a consequence of reduction in 2,3,5-triphenyltetrazolium chloride (TTC) with dehydrogenase [76]. Seedling roots were cut off on ice and incubated with $1 \mathrm{~mL}$ of $0.4 \%$ TTC (Serva; Heidelberg, Germany) for $24 \mathrm{~h}$ at room temperature in the dark. Next, the roots were washed with distilled water, transferred to new tubes and flooded with $0.5 \mathrm{~mL}$ of $95 \%$ ethanol. The samples were homogenized with Tissue Lyser II (Qiagen, Hilden, Germany) and incubated at $55^{\circ} \mathrm{C}$ for one hour. After that, another $0.5 \mathrm{~mL}$ of $95 \%$ ethanol was added to the samples, which were then vortexed and centrifuged for $3 \mathrm{~min}$ at $10,000 \mathrm{rcf}$. Volumes of $800 \mu \mathrm{L}$ of supernatant and $1400 \mu \mathrm{L}$ of $95 \%$ ethanol were mixed in the spectrophotometer cuvette and the absorbance of the samples was measured at $\lambda=485$. Each experiment was repeated four times.

\subsection{Lipid Peroxidation Determination}

For assessment of lipid peroxidation in seedling roots, the amount of thiobarbituric acid-reactive substances (TBARS) was measured, according to the method described in [77] with some modifications. Whole roots of seedlings (approximately $200 \mathrm{mg}$ ) were cut off on ice and homogenized with $3 \mathrm{~mL}$ of 10\% TCA (Sigma-Aldrich, TO699, St. Louis, MO, USA). Thereafter, the samples were centrifuged $\left(12,000 \mathrm{rpm}, 4^{\circ} \mathrm{C}, 10 \mathrm{~min}\right)$ and $1 \mathrm{~mL}$ of supernatant was transferred to glass tubes, filled with $4 \mathrm{~mL}$ of $0.5 \%$ TBA dissolved in $10 \%$ TCA. After incubation at $95^{\circ} \mathrm{C}$ for $30 \mathrm{~min}$, the samples were cooled. Next, they were mixed by inversion and centrifuged ( $5000 \mathrm{rpm}, 4^{\circ} \mathrm{C}, 2 \mathrm{~min}$ ). The absorbance of the supernatant was measured at $532 \mathrm{~nm}$ and corrected for unspecific absorbance at $600 \mathrm{~nm}(0.5 \%$ TBA in $10 \%$ TCA was used as a blank). Each experiment was repeated four times and all samples in each experiment were tested in duplicate.

\subsection{Statistics}

Statistical analyses were performed using Statistica 13.3 for Windows (StatSoft, Kraków, Poland). Differences in length and mass of the seedlings, as well as germination rate between treatments were analyse with nonparametric Kruskal-Wallis test. For cell viability and lipid peroxidation quantification, analysis of variance (ANOVA) was used, followed by the Tukey's post hoc test (if needed). Data are shown as a mean \pm standard error (SE).

\section{Conclusions}

To summarize, there is no evidence for the toxic effects of $\mathrm{GdVO}_{4}: \mathrm{Eu}^{3+} \mathrm{NPs}$ on vascular plants when used in concentrations of $100 \mu \mathrm{g} / \mathrm{mL}$ and lower. After three days of incubation, $\mathrm{GdVO}_{4}: \mathrm{Eu}^{3+} \mathrm{NPs}$ did not affect the number of roots, root length, root mass, hypocotyl length and hypocotyl mass, as well as the germination rate of the wheat seedlings. On the other hand, root cells of the treated seedlings contained less Evans Blue (EB) when compared to the control. The observed decrease in the Evans Blue level indicates that LDNCs affect membrane functioning. The mechanism of that interaction is not known. Thus, it would be interesting to obtain more detailed insights into the effect of these NPs on plants physiology. 
Author Contributions: Conceptualization, A.E.-G. and J.C.-B.; methodology, A.E.-G. and J.C.-B.; software, A.E.-G.; validation, A.E.-G. and J.C.-B.; formal analysis, A.E.-G. and J.C.-B.; investigation, A.E.-G., J.C.-B. and A.S.; data curation, A.E.-G.; writing-original draft preparation, A.E.-G.; writingreview and editing, A.E.-G., J.C.-B. and A.S.; visualization, A.E.-G. and A.S.; supervision, A.E.-G.; project administration, A.E.-G.; funding acquisition, A.E.-G. All authors have read and agreed to the published version of the manuscript.

Funding: This research was funded by the National Science Centre, Poland, grant number UMO2016/23/D/NZ8/01112.

Institutional Review Board Statement: Not applicable.

Informed Consent Statement: Not applicable.

Conflicts of Interest: The authors declare no conflict of interest.

\section{References}

1. Judy, J.D.; Bertsch, P.M. Bioavailability, Toxicity, and Fate of Manufactured Nanomaterials in Terrestrial Ecosystems; Elsevier BV: Amsterdam, The Netherlands, 2014; Volume 123, pp. 1-64.

2. Bystrzejewska-Piotrowska, G.; Golimowski, J.; Urban, P.L. Nanoparticles: Their potential toxicity, waste and environmental management. Waste Manag. 2009, 29, 2587-2595. [CrossRef] [PubMed]

3. Peralta-Videa, J.R.; Zhao, L.; Lopez-Moreno, M.L.; de la Rosa, G.; Hong, J.; Gardea-Torresdey, J.L. Nanomaterials and the environment: A review for the biennium 2008-2010. J. Hazard. Mater. 2011, 186, 1-15. [CrossRef]

4. Hawthorne, J.; Roche, R.D.L.T.; Xing, B.; Newman, L.A.; Ma, X.; Majumdar, S.; Gardea-Torresdey, J.; White, J.C. Particle-Size Dependent Accumulation and Trophic Transfer of Cerium Oxide through a Terrestrial Food Chain. Environ. Sci. Technol. 2014, 48, 13102-13109. [CrossRef]

5. Roche, R.D.L.T.; Servin, A.; Hawthorne, J.; Xing, B.; Newman, L.A.; Ma, X.; Chen, G.; White, J.C. Terrestrial Trophic Transfer of Bulk and Nanoparticle La2O3 Does Not Depend on Particle Size. Environ. Sci. Technol. 2015, 49, 11866-11874. [CrossRef] [PubMed]

6. Modlitbová, P.; Novotný, K.; Pořízka, P.; Klus, J.; Lubal, P.; Zlámalová-Gargošová, H.; Kaiser, J. Comparative investigation of toxicity and bioaccumulation of Cd-based quantum dots and $\mathrm{Cd}$ salt in freshwater plant Lemna minor L. Ecotoxicol. Environ. Saf. 2018, 147, 334-341. [CrossRef]

7. Lead, J.R.; Batley, G.E.; Alvarez, P.; Croteau, M.-N.; Handy, R.D.; McLaughlin, M.J.; Judy, J.D.; Schirmer, K. Nanomaterials in the environment: Behavior, fate, bioavailability, and effects-An updated review. Environ. Toxicol. Chem. 2018, 37, $2029-2063$. [CrossRef]

8. Ma, Y.; Zhang, P.; Zhang, Z.; He, X.; Li, Y.; Zhang, J.; Zheng, L.; Chu, S.; Yang, K.; Zhao, Y.; et al. Origin of the different phytotoxicity and biotransformation of cerium and lanthanum oxide nanoparticles in cucumber. Nanotoxicology 2015, 9, 262-270. [CrossRef]

9. Nordmann, J.; Buczka, S.; Voss, B.; Haase, M.; Mummenhoff, K. In vivo analysis of the size- and time-dependent uptake of NaYF4:Yb,Er upconversion nanocrystals by pumpkin seedlings. J. Mater. Chem. B 2014, 3, 144-150. [CrossRef] [PubMed]

10. Hischemöller, A.; Nordmann, J.; Ptacek, P.; Mummenhoff, K.; Haase, M. In-Vivo Imaging of the Uptake of Upconversion Nanoparticles by Plant Roots. J. Biomed. Nanotechnol. 2009, 5, 278-284. [CrossRef] [PubMed]

11. Yusefi-Tanha, E.; Fallah, S.; Rostamnejadi, A.; Pokhrel, L.R. Root System Architecture, Copper Uptake and Tissue Distribution in Soybean (Glycine max (L.) Merr.) Grown in Copper Oxide Nanoparticle (CuONP)-Amended Soil and Implications for Human Nutrition. Plants 2020, 9, 1326. [CrossRef] [PubMed]

12. Ma, X.; Geisler-Lee, J.; Deng, Y.; Kolmakov, A. Interactions between engineered nanoparticles (ENPs) and plants: Phytotoxicity, uptake and accumulation. Sci. Total Environ. 2010, 408, 3053-3061. [CrossRef]

13. Ma, C.; White, J.C.; Dhankher, O.P.; Xing, B. Metal-Based Nanotoxicity and Detoxification Pathways in Higher Plants. Environ. Sci. Technol. 2015, 49, 7109-7122. [CrossRef] [PubMed]

14. Kulacki, K.J.; Cardinale, B.J. Effects of Nano-Titanium Dioxide on Freshwater Algal Population Dynamics. PLoS ONE 2012, 7, e47130. [CrossRef]

15. Hao, Y.; Ma, C.; Zhang, Z.; Song, Y.; Cao, W.; Guo, J.; Zhou, G.; Rui, Y.; Liu, L.; Xing, B. Carbon nanomaterials alter plant physiology and soil bacterial community composition in a rice-soil-bacterial ecosystem. Environ. Pollut. 2018, 232, 123-136. [CrossRef]

16. Yin, W.; Zhou, L.; Ma, Y.; Tian, G.; Zhao, J.; Yan, L.; Zheng, X.; Zhang, P.; Yu, J.; Gu, Z.; et al. Phytotoxicity, Translocation, and Biotransformation of NaYF4Upconversion Nanoparticles in a Soybean Plant. Small 2015, 11, 4774-4784. [CrossRef] [PubMed]

17. Peng, J.; Sun, Y.; Liu, Q.; Yang, Y.; Zhou, J.; Feng, W.; Zhang, X.; Li, F. Upconversion nanoparticles dramatically promote plant growth without toxicity. Nano Res. 2012, 5, 770-782. [CrossRef]

18. Joonas, E.; Aruoja, V.; Olli, K.; Syvertsen-Wiig, G.; Vija, H.; Kahru, A. Potency of (doped) rare earth oxide particles and their constituent metals to inhibit algal growth and induce direct toxic effects. Sci. Total Environ. 2017, 593-594, 478-486. [CrossRef] [PubMed] 
19. Ma, Y.; Xie, C.; He, X.; Zhang, B.; Yang, J.; Sun, M.; Luo, W.; Feng, S.; Zhang, J.; Wang, G.; et al. Effects of Ceria Nanoparticles and $\mathrm{CeCl} 3$ on Plant Growth, Biological and Physiological Parameters, and Nutritional Value of Soil Grown Common Bean (Phaseolus vulgaris). Small 2020, 16, e1907435. [CrossRef]

20. Lee, W.-M.; An, Y.-J.; Yoon, H.; Kweon, H.-S. Toxicity and Bioavailability of Copper Nanoparticles to the Terrestrial Plants Mung Bean (PHASEOLUS RADIATUS) and Wheat (TRITICUM AESTIVUM): Plant Agar Test for Water-Insolube Nanoparticles. Environ. Toxicol. Chem. 2008, 27, 1915-1921. [CrossRef]

21. Oukarroum, A.; Barhoumi, L.; Pirastru, L.; Dewez, D. Silver nanoparticle toxicity effect on growth and cellular viability of the aquatic plant Lemna gibba. Environ. Toxicol. Chem. 2013, 32, 902-907. [CrossRef] [PubMed]

22. Andersen, C.P.; King, G.; Plocher, M.; Storm, M.; Pokhrel, L.R.; Johnson, M.G.; Rygiewicz, P.T. Germination and early plant development of ten plant species exposed to titanium dioxide and cerium oxide nanoparticles. Environ. Toxicol. Chem. 2016, 35, 2223-2229. [CrossRef] [PubMed]

23. Li, Z.; Juneau, P.; Lian, Y.; Zhang, W.; Wang, S.; Wang, C.; Shu, L.; Yan, Q.; He, Z.; Xu, K. Effects of Titanium Dioxide Nanoparticles on Photosynthetic and Antioxidative Processes of Scenedesmus obliquus. Plants 2020, 9, 1748. [CrossRef] [PubMed]

24. Libralato, G.; Devoti, A.C.; Zanella, M.; Sabbioni, E.; Mičetić, I.; Manodori, L.; Pigozzo, A.; Manenti, S.; Groppi, F.; Ghirardini, A.V. Phytotoxicity of ionic, micro- and nano-sized iron in three plant species. Ecotoxicol. Environ. Saf. 2016, 123, 81-88. [CrossRef]

25. Gavina, A.; Bouguerra, S.; Lopes, I.; Marques, C.; Rasteiro, M.; Antunes, F.; Rocha-Santos, T.; Pereira, R. Impact of organic nano-vesicles in soil: The case of sodium dodecyl sulphate/didodecyl dimethylammonium bromide. Sci. Total Environ. 2016, 547, 413-421. [CrossRef]

26. Khodakovskaya, M.; Dervishi, E.; Mahmood, M.; Xu, Y.; Li, Z.; Watanabe, F.; Biris, A.S. Carbon Nanotubes Are Able To Penetrate Plant Seed Coat and Dramatically Affect Seed Germination and Plant Growth. ACS Nano 2009, 3, 3221-3227. [CrossRef] [PubMed]

27. Lian, J.; Wu, J.; Xiong, H.; Zeb, A.; Yang, T.; Su, X.; Su, L.; Liu, W. Impact of polystyrene nanoplastics (PSNPs) on seed germination and seedling growth of wheat (Triticum aestivum L.). J. Hazard. Mater. 2020, 385, 121620. [CrossRef] [PubMed]

28. Hayes, K.L.; Mui, J.; Song, B.; Sani, E.S.; Eisenman, S.W.; Sheffield, J.B.; Kim, B. Effects, uptake, and translocation of aluminum oxide nanoparticles in lettuce: A comparison study to phytotoxic aluminum ions. Sci. Total Environ. 2020, 719, 137393. [CrossRef]

29. Romero-Freire, A.; Joonas, E.; Muna, M.; Cossu-Leguille, C.; Vignati, D.; Giamberini, L. Assessment of the toxic effects of mixtures of three lanthanides (Ce, Gd, Lu) to aquatic biota. Sci. Total Environ. 2019, 661, 276-284. [CrossRef] [PubMed]

30. Mohmood, I.; Lopes, C.B.; Lopes, I.; Tavares, D.S.; Soares, A.M.; Duarte, A.; Trindade, T.; Ahmad, I.; Pereira, E. Remediation of mercury contaminated saltwater with functionalized silica coated magnetite nanoparticles. Sci. Total Environ. 2016, 557-558, 712-721. [CrossRef]

31. Hu, C.; Liu, L.; Li, X.; Xu, Y.; Ge, Z.; Zhao, Y. Effect of graphene oxide on copper stress in Lemna minor L.: Evaluating growth, biochemical responses, and nutrient uptake. J. Hazard. Mater. 2018, 341, 168-176. [CrossRef]

32. Silva, S.; Oliveira, H.; Craveiro, S.C.; Calado, A.J.; Santos, C. Pure anatase and rutile + anatase nanoparticles differently affect wheat seedlings. Chemosphere 2016, 151, 68-75. [CrossRef] [PubMed]

33. Monteiro, C.; Daniel-Da-Silva, A.L.; Venâncio, C.; Soares, S.; Soares, A.M.; Trindade, T.; Lopes, I. Effects of long-term exposure to colloidal gold nanorods on freshwater microalgae. Sci. Total Environ. 2019, 682, 70-79. [CrossRef] [PubMed]

34. Thiagarajan, V.; Pavani, M.; Archanaa, S.; Seenivasan, R.; Chandrasekaran, N.; Suraishkumar, G.K.; Mukherjee, A. Diminishing bioavailability and toxicity of P25 TiO2 NPs during continuous exposure to marine algae Chlorella sp. Chemosphere 2019, 233, 363-372. [CrossRef]

35. Silva, S.; Oliveira, H.; Silva, A.; Santos, C. The cytotoxic targets of anatase or rutile + anatase nanoparticles depend on the plant species. Biol. Plant. 2017, 61,717-725. [CrossRef]

36. Mazierski, P.; Sowik, J.; Miodyńska, M.; Trykowski, G.; Mikolajczyk, A.; Klimczuk, T.; Lisowski, W.; Nadolna, J.; ZaleskaMedynska, A. Shape-controllable synthesis of GdVO4 photocatalysts and their tunable properties in photocatalytic hydrogen generation. Dalton Trans. 2019, 48, 1662-1671. [CrossRef]

37. Wang, D.; Zhao, C.; Gao, G.; Xu, L.; Wang, G.; Zhu, P. Multifunctional NaLnF4@MOF-Ln Nanocomposites with Dual-Mode Luminescence for Drug Delivery and Cell Imaging. Nanomaterials 2019, 9, 1274. [CrossRef] [PubMed]

38. Sun, N.; Ding, Y.; Tao, Z.; You, H.; Hua, X.; Wang, M. Development of an upconversion fluorescence DNA probe for the detection of acetamiprid by magnetic nanoparticles separation. Food Chem. 2018, 257, 289-294. [CrossRef] [PubMed]

39. Wysokińska, E.; Cichos, J.; Kowalczyk, A.; Karbowiak, M.; Strządała, L.; Bednarkiewicz, A.; Kałas, W. Toxicity Mechanism of Low Doses of NaGdF4:Yb3+,Er3+ Upconverting Nanoparticles in Activated Macrophage Cell Lines. Biomolecules 2019,9 , 14. [CrossRef]

40. Dong, R.; Li, Y.; Li, W.; Zhang, H.; Liu, Y.; Ma, L.; Wang, X.; Lei, B. Recent developments in luminescent nanoparticles for plant imaging and photosynthesis. J. Rare Earths 2019, 37, 903-915. [CrossRef]

41. Szczeszaka, A.; Grzyba, T.; Nowaczykb, G.; Grzybc, A.E. Emission colour changes in the CaF2 sub-microspheres doped with $\mathrm{Yb3}+$, Er3+ and Mn2+ ions. J. Alloy. Compd. 2020, 817, 152718. [CrossRef]

42. Szczeszak, A.; Grzyb, T.; Śniadecki, Z.; Andrzejewska, N.; Lis, S.; Matczak, M.; Nowaczyk, G.; Jurga, S.; Idzikowski, B. Structural, Spectroscopic, and Magnetic Properties of Eu3+-Doped GdVO4 Nanocrystals Synthesized by a Hydrothermal Method. Inorg. Chem. 2014, 53, 12243-12252. [CrossRef]

43. Thakur, H.; Singh, R.K.; Gathania, A.K. Synthesis and optical properties of GdVO4: Eu3+ phosphor. Mater. Res. Express 2021, 8, 026201. [CrossRef] 
44. Nuñez, N.O.; Rivera, S.; Alcantara, D.; De La Fuente, J.M.; García-Sevillano, J.; Ocaña, M. Surface modified Eu:GdVO4 nanocrystals for optical and MRI imaging. Dalton Trans. 2013, 42, 10725-10734. [CrossRef] [PubMed]

45. Lin, W.; Huang, Y.-W.; Zhou, X.-D.; Ma, Y. In vitro toxicity of silica nanoparticles in human lung cancer cells. Toxicol. Appl. Pharmacol. 2006, 217, 252-259. [CrossRef] [PubMed]

46. Kim, T.; Lee, N.; Park, Y.I.; Kim, J.; Kim, J.; Lee, E.Y.; Yi, M.; Kim, B.-G.; Hyeon, T.; Yu, T.; et al. Mesoporous silica-coated luminescent Eu3+doped GdVO4nanoparticles for multimodal imaging and drug delivery. RSC Adv. 2014, 4, 45687-45695. [CrossRef]

47. Yin, W.; Zhou, L.; Gu, Z.; Tian, G.; Jin, S.; Yan, L.; Liu, X.; Xing, G.; Ren, W.; Liu, F.; et al. Lanthanide-doped GdVO4 upconversion nanophosphors with tunable emissions and their applications for biomedical imaging. J. Mater. Chem. 2012, 22, 6974-6981. [CrossRef]

48. Zhu, G.; Chen, L.; Zeng, F.; Gu, L.; Yu, X.; Li, X.; Jiang, J.; Guo, G.; Cao, J.; Tang, K.; et al. GdVO4:Eu3+,Bi3+ Nanoparticles as a Contrast Agent for MRI and Luminescence Bioimaging. ACS Omega 2019, 4, 15806-15814. [CrossRef] [PubMed]

49. Abdesselem, M.; Ramodiharilafy, R.; Devys, L.; Gacoin, T.; Alexandrou, A.; Bouzigues, C.I.; Adesselem, M. Fast quantitative ROS detection based on dual-color single rare-earth nanoparticle imaging reveals signaling pathway kinetics in living cells. Nanoscale 2016, 9, 656-665. [CrossRef]

50. Hatje, V.; Bruland, K.W.; Flegal, A.R. Increases in Anthropogenic Gadolinium Anomalies and Rare Earth Element Concentrations in San Francisco Bay over a 20 Year Record. Environ. Sci. Technol. 2016, 50, 4159-4168. [CrossRef]

51. Kanda, T.; Fukusato, T.; Matsuda, M.; Toyoda, K.; Oba, H.; Kotoku, J.; Haruyama, T.; Kitajima, K.; Furui, S. Gadolinium-based Contrast Agent Accumulates in the Brain Even in Subjects without Severe Renal Dysfunction: Evaluation of Autopsy Brain Specimens with Inductively Coupled Plasma Mass Spectroscopy. Radiology 2015, 276, 228-232. [CrossRef]

52. Mizgerd, J.P.; Molina, R.M.; Stearns, R.C.; Brain, J.D.; E Warner, A. Gadolinium induces macrophage apoptosis. J. Leukoc. Biol. 1996, 59, 189-195. [CrossRef]

53. Szczeszak, A.; Ekner-Grzyb, A.; Runowski, M.; Mrówczyńska, L.; Grzyb, T.; Lis, S. Synthesis, photophysical analysis, and in vitro cytotoxicity assessment of the multifunctional (magnetic and luminescent) core@shell nanomaterial based on lanthanide-doped orthovanadates. J. Nanoparticle Res. 2015, 17, 1-11. [CrossRef]

54. Szczeszak, A.; Ekner-Grzyb, A.; Runowski, M.; Szutkowski, K.; Mrówczyńska, L.; Kaźmierczak, Z.; Grzyb, T.; Dąbrowska, K.; Giersig, M.; Lis, S. Spectroscopic, structural and in vitro cytotoxicity evaluation of luminescent, lanthanide doped core@shell nanomaterials GdVO4:Eu3+5\%@SiO2@NH2. J. Colloid Interface Sci. 2016, 481, 245-255. [CrossRef]

55. Modlitbová, P.; Hlaváček, A.; Švestková, T.; Pořízka, P.; Šimoníková, L.; Novotný, K.; Kaiser, J. The effects of photon-upconversion nanoparticles on the growth of radish and duckweed: Bioaccumulation, imaging, and spectroscopic studies. Chemosphere 2019, 225, 723-734. [CrossRef]

56. Blinova, I.; Muna, M.; Heinlaan, M.; Lukjanova, A.; Kahru, A. Potential Hazard of Lanthanides and Lanthanide-Based Nanoparticles to Aquatic Ecosystems: Data Gaps, Challenges and Future Research Needs Derived from Bibliometric Analysis. Nanomaterials 2020, 10, 328. [CrossRef]

57. Hu, S.; Wu, X.; Chen, Z.; Hu, P.; Yan, H.; Tang, Z.; Xi, Z.; Liu, Y. Uniform NaLuF 4 nanoparticles with strong upconversion luminescence for background-free imaging of plant cells and ultralow power detecting of trace organic dyes. Mater. Res. Bull. 2016, 73, 6-13. [CrossRef]

58. Gnach, A.; Lipinski, T.; Bednarkiewicz, A.; Rybka, J.; Capobianco, J.A. Upconverting nanoparticles: Assessing the toxicity. Chem. Soc. Rev. 2015, 44, 1561-1584. [CrossRef]

59. Blinova, I.; Vija, H.; Lukjanova, A.; Muna, M.; Syvertsen-Wiig, G.; Kahru, A. Assessment of the hazard of nine (doped) lanthanides-based ceramic oxides to four aquatic species. Sci. Total Environ. 2018, 612, 1171-1176. [CrossRef] [PubMed]

60. Ma, Y.; Kuang, L.; He, X.; Bai, W.; Ding, Y.; Zhang, Z.; Zhao, Y.; Chai, Z. Effects of rare earth oxide nanoparticles on root elongation of plants. Chemosphere 2010, 78, 273-279. [CrossRef] [PubMed]

61. Saatz, J.; Vetterlein, D.; Mattusch, J.; Otto, M.; Daus, B. The influence of gadolinium and yttrium on biomass production and nutrient balance of maize plants. Environ. Pollut. 2015, 204, 32-38. [CrossRef]

62. Ruíz-Herrera, L.F.; Sánchez-Calderón, L.; Herrera-Estrella, L.R.; López-Bucio, J. Rare earth elements lanthanum and gadolinium induce phosphate-deficiency responses in Arabidopsis thaliana seedlings. Plant Soil 2011, 353, 231-247. [CrossRef]

63. Tian, H.E.; Gao, Y.S.; Li, F.M.; Zeng, F. Effects of europium ions (Eu3+) on the distribution and related biological activities of elements in Lathyrus sativus L roots. Biol. Trace Element Res. 2003, 93, 257-270. [CrossRef]

64. Shtangeeva, I. Europium and Cerium Accumulation in Wheat and Rye Seedlings. Water Air Soil Pollut. 2014, 225, 1-13. [CrossRef]

65. García-Jiménez, A.; Trejo-Téllez, L.I.; Guillén-Sánchez, D.; Gómez-Merino, F.C. Vanadium stimulates pepper plant growth and flowering, increases concentrations of amino acids, sugars and chlorophylls, and modifies nutrient concentrations. PLoS ONE 2018, 13, e0201908. [CrossRef] [PubMed]

66. Aihemaiti, A.; Gao, Y.; Meng, Y.; Chen, X.; Liu, J.; Xiang, H.; Xu, Y.; Jiang, J. Review of plant-vanadium physiological interactions, bioaccumulation, and bioremediation of vanadium-contaminated sites. Sci. Total Environ. 2020, 712, 135637. [CrossRef]

67. Noman, M.; Shahid, M.; Ahmed, T.; Tahir, M.; Naqqash, T.; Muhammad, S.; Song, F.; Abid, H.M.A.; Aslam, Z. Green copper nanoparticles from a native Klebsiella pneumoniae strain alleviated oxidative stress impairment of wheat plants by reducing the chromium bioavailability and increasing the growth. Ecotoxicol. Environ. Saf. 2020, 192, 110303. [CrossRef] 
68. Silva, S.; Craveiro, S.C.; Oliveira, H.; Calado, A.J.; Pinto, R.J.; Silva, A.M.; Santos, C. Wheat chronic exposure to TiO 2 -nanoparticles: Cyto- and genotoxic approach. Plant Physiol. Biochem. 2017, 121, 89-98. [CrossRef]

69. Yusefi-Tanha, E.; Fallah, S.; Rostamnejadi, A.; Pokhrel, L.R. Particle size and concentration dependent toxicity of copper oxide nanoparticles (CuONPs) on seed yield and antioxidant defense system in soil grown soybean (Glycine max cv. Kowsar). Sci. Total Environ. 2020, 715, 136994. [CrossRef] [PubMed]

70. Soares, C.; Branco-Neves, S.; De Sousa, A.; Pereira, R.; Fidalgo, F. Ecotoxicological relevance of nano-NiO and acetaminophen to Hordeum vulgare L.: Combining standardized procedures and physiological endpoints. Chemosphere 2016, 165, 442-452. [CrossRef] [PubMed]

71. Imtiaz, M.; Ashraf, M.; Rizwan, M.S.; Nawaz, M.A.; Mehmood, S.; Yousaf, B.; Yuan, Y.; Ditta, A.; Mumtaz, M.A.; Ali, M.; et al. Vanadium toxicity in chickpea (Cicer arietinum L.) grown in red soil: Effects on cell death, ROS and antioxidative systems. Ecotoxicol. Environ. Saf. 2018, 158, 139-144. [CrossRef] [PubMed]

72. Baker, C.J.; Mock, N.M. An improved method for monitoring cell death in cell suspension and leaf disc assays using evans blue. Plant Cell Tissue Organ Cult. (PCTOC) 1994, 39, 7-12. [CrossRef]

73. Contini, C.; Schneemilch, M.; Gaisford, S.; Quirke, N. Nanoparticle-membrane interactions. J. Exp. Nanosci. $2018,13,62-81$. [CrossRef]

74. Chmielowska-Bąk, J.; Holubek, R.; Frontasyeva, M.; Zinicovscaia, I.; Işidoğru, S.; Deckert, J. Tough Sprouting - Impact of Cadmium on Physiological State and Germination Rate of Soybean Seeds. Acta Soc. Bot. Pol. 2020, 89. [CrossRef]

75. Abdesselem, M.; Schoeffel, M.; Maurin, I.; Ramodiharilafy, R.; Autret, G.; Clément, O.; Tharaux, P.-L.; Boilot, J.-P.; Gacoin, T.; Bouzigues, C.; et al. Multifunctional Rare-Earth Vanadate Nanoparticles: Luminescent Labels, Oxidant Sensors, and MRI Contrast Agents. ACS Nano 2014, 8, 11126-11137. [CrossRef]

76. Towill, L.E.; Mazur, P. Studies on the reduction of 2,3,5-triphenyltetrazolium chloride as a viability assay for plant tissue cultures. Can. J. Bot. 1975, 53, 1097-1102. [CrossRef]

77. Heath, R.L.; Packer, L. Photoperoxidation in isolated chloroplasts. Arch. Biochem. Biophys. 1968, 125, 189-198. [CrossRef] 